\title{
Enhanced rooftop rainwater harvesting quality through filtration using zeolite and activated carbon
}

\author{
Anie Yulistyorini ${ }^{1}{ }^{*}$, Gilang $\operatorname{Idfi}^{1}$ and Evy Dwi Fahmi ${ }^{1}$ \\ ${ }^{1}$ Civil Engineering Department, Faculty of Engineering, State University of Malang, 65145 Malang, \\ Indonesia
}

\begin{abstract}
This study aimed to investigate the quality of the rooftop rainwater harvesting (RRWH) and to treat it for clean water supply alternative of Graha Rektorat building at State University of Malang, Indonesia. Different combinations of zeolite and activated carbon were used as filter media to treat the RRWH. Several parameters have tested to investigate the quality of RRWH based on Permenkes RI No. 416 / MENKES / PER / IX / 1990. Most of the quality of the RRWH met clean water and drinking water standard. However, there were three parameters have to be reduced and required further treatment. The results showed T4 reduced TDS and coliform bacteria by $37 \%$ and $36 \%$, while T5 eliminated organic substances $(\mathrm{KMnO} 4)$ for $35 \%$.
\end{abstract}

\section{Introduction}

Increasing urban population has influenced the high demand for clean water consumption. It affects not only the increase in water demand but also the quality and quantity of water sources in urban areas (1). Rainwater has become an alternative for water scarcity problem in which pure and accessible water can harvest through rainwater harvesting (RWH) system (2). Especially in Malang, the clean water is obtained from spring water located in the suburban of the city that managed by the local water company (PDAM). However, due to a limited quantity of clean water that can be supplied by PDAM Malang and an escalation of the urban population, the optimum clean water distribution become a crucial problem. Hence, implementation of RRWH can reduce the use of water consumption that supplied by PDAM. For instance, the use of RWH for homes, shops, apartments and buildings in Malang city decreased the water consumption by $30-40 \%$ (3).

Rainwater treatment is needed before it is used for clean water consumption. The Chemical Engineering Department of Jessore University conducted physical and chemical tests on rainwater samples taken from rural areas of Bangladesh. The study reported that dissolved solids concentration was low and therefore, rainwater samples do not contain

\footnotetext{
* Corresponding author: anie.yulistyorini.ft@um.ac.id
} 
harmful substances and suitable for drinking water (4). However, rainwater component in rural and city areas is different due to the effect of the air pollution. The rainwater pollutant can reduce through physical, chemical and biological filtration (5). Zeolite and activated carbon are low-cost media used for water filtration. Zeolite has a cavity/pore that able to absorb solids through the physical and chemical process (6). Moreover, active carbon and zeolite can reduce turbidity and iron concentration, but their combination can increase the $\mathrm{pH}$ of the water in wastewater treatment (7).

This study investigated the effectivity of the combination of zeolite and activated carbon as rainwater filter media in different portion. Treated rainwater that meets the standard clean water quality can utilise as an alternative source of water for the urban including the academic community in the campus of the State University of Malang. The water supply from PDAM often interferes with the technical matter, and the quantity is lower than the water demand, and therefore an alternative source of fresh water must be assessed.

\section{Research Methods}

The case study conducted at the Rektorat building of the State University of Malang, Indonesia because it requires a high amount of clean water for daily use. The quantity of rainwater determined from rainwater fall at the rooftop of the rectorate building as the amount of RHR treated through RWH system. Rainwater sampling and analysis conducted from November 2017 to March 2018 (Table 1).

Table 1. Raw rainwater sampling period

\begin{tabular}{|c|c|}
\hline Sample & Period \\
\hline First raw rainwater & $6^{\text {th }}$ November 2017 \\
\hline Treatment 1 (T1) & $9^{\text {th }}$ February 2018 \\
\hline Treatment 2 (T2) & $13^{\text {th }}$ February 2018 \\
\hline Treatment 3 (T3) & $16^{\text {th }}$ February 2018 \\
\hline Treatment 4 (T4) & $19^{\text {th }}$ February 2018 \\
\hline Treatment 5 (T5) & $22^{\text {nd }}$ February 2018 \\
\hline
\end{tabular}

The filter media of RWH system consists of a storage tank with a capacity of 42 litres (35 $\mathrm{cm} \times 35 \mathrm{~cm} \times 40 \mathrm{~cm})$. Tub filtration made of measuring glass $(50 \mathrm{~cm} \times 40 \mathrm{~cm} \times 20 \mathrm{~cm})$ with a freeboard height $15 \mathrm{~cm}$. The rainwater distribution pipe consists of a $1 / 2$-inch $(\varnothing)$ PVC pipe, a 1/2-inch 1/2-inch (Ø) gate valve, and a 1/2-inch (Ø) water tap (Figure 1).

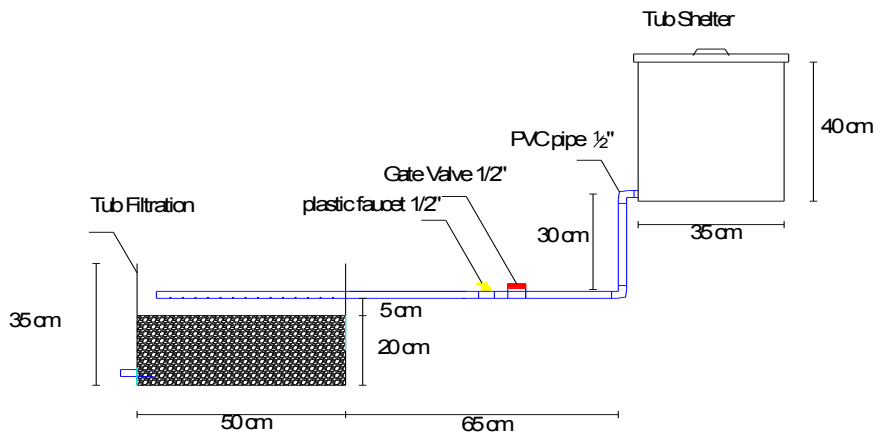

Fig. 1. Design of the RRWH filter media system

The experiment was conducted to obtain the appropriate filter media combination consisting of zeolite and activated carbon. They were five experiments arrangement of filter 
media used for rainwater treatment. Those arrangements were T1 (100\% activated carbon), T2 $(75 \%$ activated carbon $+25 \%$ zeolite $)$, T3 (50\% activated carbon $+50 \%$ zeolite), T4 ( $25 \%$ activated carbon $+75 \%$ zeolite), and T5 (100\% zeolite). The water sampling was collected from the inlet and outlet with triplicate and tested for total dissolved solids (TDS), Organic substances $\mathrm{KMnO}_{4}$, Coliform, $\mathrm{pH}$, and temperature. Laboratory analysis of the collected untreated and treated rainwater performed in Perum Jasa Tirta 1 Malang laboratory (Table 2).

Table 2. Laboratory analysis method

\begin{tabular}{|c|c|}
\hline Parameter & Method \\
\hline $\mathrm{TDS}$ & APHA 2540 C-2005 \\
\hline $\mathrm{KMnO}_{4}$ & Acid-atmosphere oxidation analysis \\
\hline Coliform & Double-tube \\
\hline $\mathrm{pH}$ & $\mathrm{pH}$ meter \\
\hline Temperature & Thermometer \\
\hline
\end{tabular}

\section{Results and Discussion}

\subsection{Untreated rainwater characteristics}

The physical, chemical, and biological characteristics results of untreated RRWH were compared to the Indonesian standard for clean water quality control (Permenkes RI No. 416 / MENKES / IX / 1990) (Table 3).

Table 3. Untreated rainwater characteristics

\begin{tabular}{|c|c|c|c|c|}
\hline Parameters & Unit & Standard & Rainwater & Description \\
\hline Turbidity & $\mathrm{NTU}$ & 25 & 12,3 & - \\
\hline $\mathrm{pH}$ & - & $6,5-9,0$ & 6,8 & - \\
\hline $\begin{array}{c}\text { Organic } \\
\text { substances } \\
\left(\mathrm{KMnO}_{4}\right)\end{array}$ & $\mathrm{mg} / \mathrm{L}$ & 10 & 16,5 & - \\
\hline $\mathrm{TDS}$ & $\mathrm{mg} / \mathrm{L}$ & 1500 & 130 & - \\
\hline $\mathrm{Cl}^{-}$ & $\mathrm{mg} / \mathrm{L}$ & 600 & 65,5 & - \\
\hline $\mathrm{NO}_{3}{ }^{-}$ & $\mathrm{mg} / \mathrm{L}$ & 10 & 2,857 & - \\
\hline $\mathrm{SO}_{4}^{2-}$ & $\mathrm{mg} / \mathrm{L}$ & 400 & 8,826 & - \\
\hline $\mathrm{Hardness}_{\mathrm{Mn}}$ & $\mathrm{mg} / \mathrm{L}$ & 500 & 10 & - \\
\hline $\mathrm{mg} / \mathrm{L}$ & 0,5 & 0,182 & - \\
\hline $\mathrm{Pb}$ & $\mathrm{mg} / \mathrm{L}$ & 0,05 & $\mathrm{tt} *)$ & $\mathrm{MDL}<0.44 \times 10^{-2}$ \\
\hline $\mathrm{Coliform}$ & $\mathrm{MPN} / 100 \mathrm{ml}$ & 9 & 50 & - \\
\hline
\end{tabular}

*) tt: unknown

MDL: Methode Detection Limit

Laboratory analysis showed that several parameters had met the standard quality of Permenkes RI No. 416 / MENKES / PER / IX / 1990. A $\mathrm{KMnO}_{4}$ concentration higher than permitted standard and require further treatment for reduction. $\mathrm{KMnO}_{4}$ or organic substances contained in RRWH may come from household activities and industrial processes, and materials derived from agricultural and livestock operations. The content of natural elements that exceed clean water quality standards can affect human health (kidneys, liver, skin and nervous system) (8), and cause the unpleasant odour in water (9). Furthermore, coliform is a group of bacteria commonly finding in the environment that usually found in the intestine of mammals including humans (10). Microbial contamination 
of raw water sources and waterborne disease remain a significant challenge in clean water treatment, and this needs to be eliminated before it uses for clean water supply (11).

\subsection{Treated rainwater characteristics}

\subsubsection{TDS concentration}

TDS is considered important in clean water consumption quality. Water-soluble TDS can be derived from natural sources, industrial waste, urban runoff, and agriculture. The presence of high TDS in water can have adverse health effects and household appliances such as water pipes and water heating (12). TDS concentration in RRWH treatment conducted in the study is shown in the following graph:

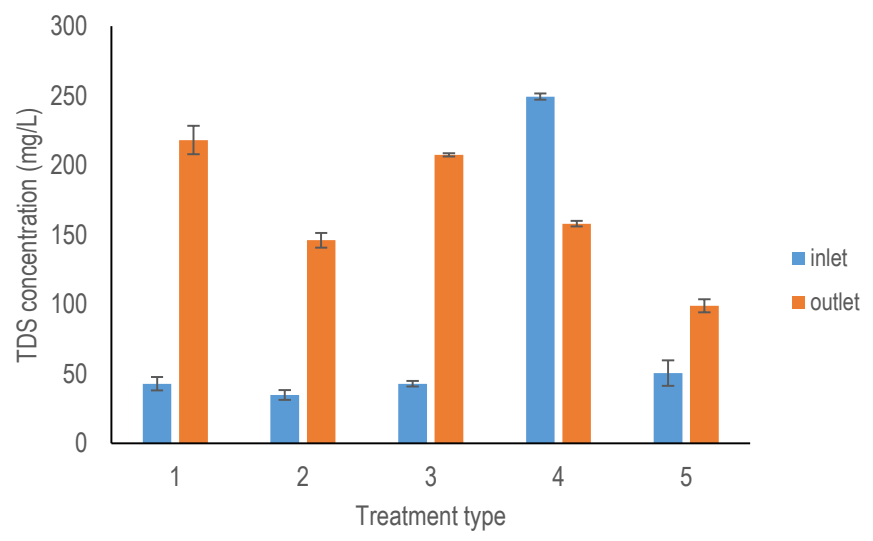

Fig. 2. TDS concentration in raw and treated RRWH

The result shows that different composition of filter media influence the solids reduction in RRWH. T4 revealed the best reduction of TDS concentration of the RRWH in which the media consist of $75 \%$ zeolite and $25 \%$ activated carbon. This treatment reduced TDS concentration for $37 \%\left(249 \mathrm{mgl}^{-1}\right.$ to $\left.158 \mathrm{mgl}^{-1}\right)$. Although, T5 showed the lowest TDS concentration of about $99 \mathrm{mgl}^{-1}$ in the affluent the pattern of the solids removal from the RRWH was similar to the other treatments (T1, T2, T3). These value met the standard of clean water quality based on Permenkes RI No.416 / MENKES / PER / IX / 1990.

The graph shows that TDS concentration in the effluent was higher in treatment 1,2, and 3. It is because the composition of activated carbon used for filter media was much higher than zeolite, and also the effect of the thickness and the irregular shape of the activated carbon. The thickness of the activated carbon layer in the filter media influences the reduction of turbidity as it is determined by the amount of total dissolved solids (TDS) $(13,14)$.

T4 and T5 used more zeolite and reduced more TDS in rainwater. Zeolite has a cavity/pore which able to filter a large number of molecules or dissolved solids in water (6). Zeolite can also filter brackish water and reduce the TDS up to $84 \%$ (15). Zeolite and activated carbon have also used to reduce the heavy metal content in pond water. However, TDS concentration in T5 increased after filtration. The increased of TDS concentration may cause by zeolite that contains chemical elements in water such as lime and can affect the TDS concentration in the water (16). 


\subsubsection{Organic substances $\left(\mathrm{KMnO}_{4}\right)$ concentration}

The presence of $\mathrm{KMnO}_{4}$ in water is closely related to the changes in physical properties of water especially colour, odour, taste, and turbidity and it leads to decrease the quality of drinking water and can cause stomach pain (17). The results of the treatment to remove $\mathrm{KMnO}_{4}$ substances in RRWH were varies, and they depend on the combination of filter media (Figure 3).

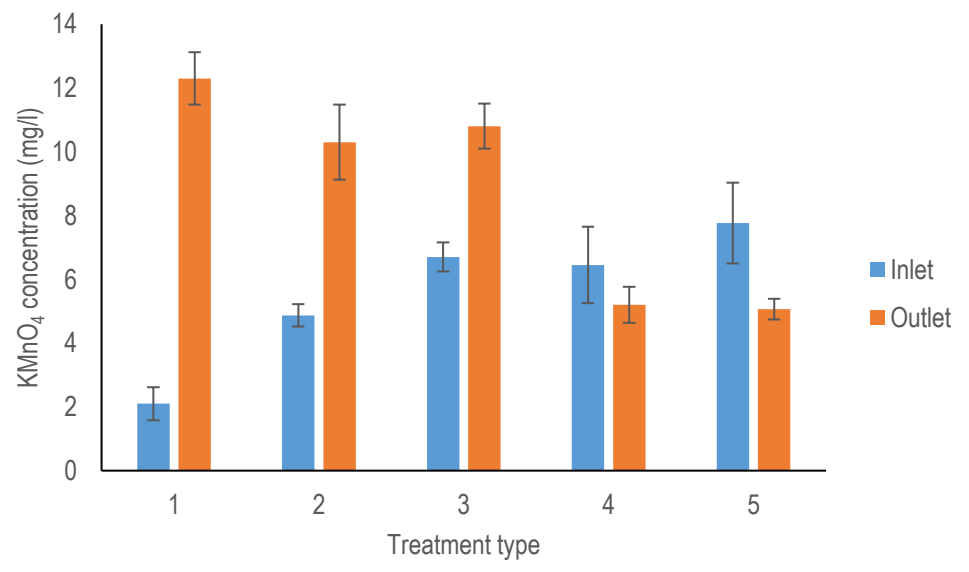

Fig. 3. $\mathrm{KMnO}_{4}$ concentration in raw and treated $\mathrm{RRWH}$

The graph demonstrates that the concentration of $\mathrm{KMnO}_{4}$ in the effluent of $\mathrm{T} 1, \mathrm{~T} 2$, and $\mathrm{T} 3$ were higher than the inlet. The concentration of $\mathrm{KMnO}_{4}$ increased from $2.1 \mathrm{mgl}^{-1}$ to $12.3 \mathrm{mgl}^{-1}, 4.87 \mathrm{mgl}^{-1}$ to $10.3 \mathrm{mgl}^{-1}$ and $6.70 \mathrm{mgl}^{-1}$ to $10.8 \mathrm{mgl}^{-1}$ respectively for $\mathrm{T} 1$, T2, and T3. Consequently, there was no reduction of $\mathrm{KMnO}_{4}$ in RRWH. Presumably, it was due to the size of $\mathrm{KMnO}_{4}$ molecule is smaller than a void in zeolite and a lower percentage of zeolite (T2) in filter media, and therefore the organic substances particles can pass the filter media (18). Whilst the concentration of $\mathrm{KMnO}_{4}$ in $\mathrm{T} 4$ and $\mathrm{T} 5$ decreased from $6.5 \mathrm{mgl}^{-1}$ to $5.2 \mathrm{mgl}^{-1}(19.4 \%)$ and from $7.8 \mathrm{mgl}^{-1}$ to $5.1 \mathrm{mgl}^{-1}$ (35\%) respectively. Moreover, $\mathrm{KMnO}_{4}$ concentration in rainwater reduced due to the portion of zeolite higher than activated carbon. In this study, T5 revealed as the best treatment for organic substances $\left(\mathrm{KMnO}_{4}\right)$ reduction in RRWH and met the Indonesian standard of water quality (Permenkes RI No.416 / MENKES / PER / IX / 1990).

The decrease of $\mathrm{KMnO}_{4}$ concentration in $\mathrm{T} 5$ is due to the pore of zeolites which able to absorb organic and inorganic substances molecules in water (19). Zeolite is also able to reduce an organic substance concentration in waste from $173.7 \mathrm{mgl}^{-1}$ to $37.5 \mathrm{mgl}^{-1}$ (20). Moreover, the use of activated carbon for peatland water filter media resulted in decreasing $\mathrm{KMnO}_{4}$ from $152.5 \mathrm{mgl}^{-1}$ to $9.6 \mathrm{mgl}^{-1}$ (92\%) (21).

\subsubsection{Coliform bacteria}

Rainwater harvesting is currently utilised as an alternative to clean water supply, but investigation of coliform contamination is critically important to consider the rainwater as a clean water source. Microbiological concentration in water cause high water turbidity and symptoms of diarrhoea, fever, nausea, vomiting, and indigestion (22) and therefore the water source must be treated before it consumes by a human (23).

The treatment results to reduce coliform bacteria in RRWH is presented in Figure 4. T1 which used $100 \%$ activated carbon decreased about $30 \%$ of coliform concentration $(11.5$ 
MPN/100ml to 7.0 MPN/100 ml). Activated carbon influenced the reduction of coliform bacteria in T1 because it can bind microorganisms contained in water (24). The use of activated carbon as a filter media can reduce the number of coliform bacteria from 1600 MPN/100 ml to $920 \mathrm{MPN} / 100 \mathrm{ml}$ of the well-water filtration in Pahlawan sub-district of Medan Perjuangan, North Sumatra (25).

The decrease of coliform concentration also occurred in T4 and T5 where the portion of zeolite was higher than activated carbon. The efficiency T4 was larger than T5 in reducing coliform bacteria of RRWH where T4 reduced coliform bacteria from $7 \mathrm{MPN} / 100 \mathrm{ml}$ to 4.5 MPN/100ml (36\%) and T5 from $7 \mathrm{MPN} / 100 \mathrm{ml}$ to $5 \mathrm{MPN} / 100 \mathrm{ml}(29 \%)$ respectively. Combination of activated carbon and zeolite in T4 revealed as the best composition in reducing coliform bacteria than $100 \%$ zeolite in T5. This evidence is in line with a study to improve the quality of well-water by using mixed zeolite and activated carbon-tile filter media (5).

On the other hand, the coliform bacteria in the effluent slightly increased in T2 and T3. Although the concentration of coliform bacteria in both treatment were higher than the inlet, the values still met the Permenkes RI No.416 / MENKES / PER / IX / 1990.

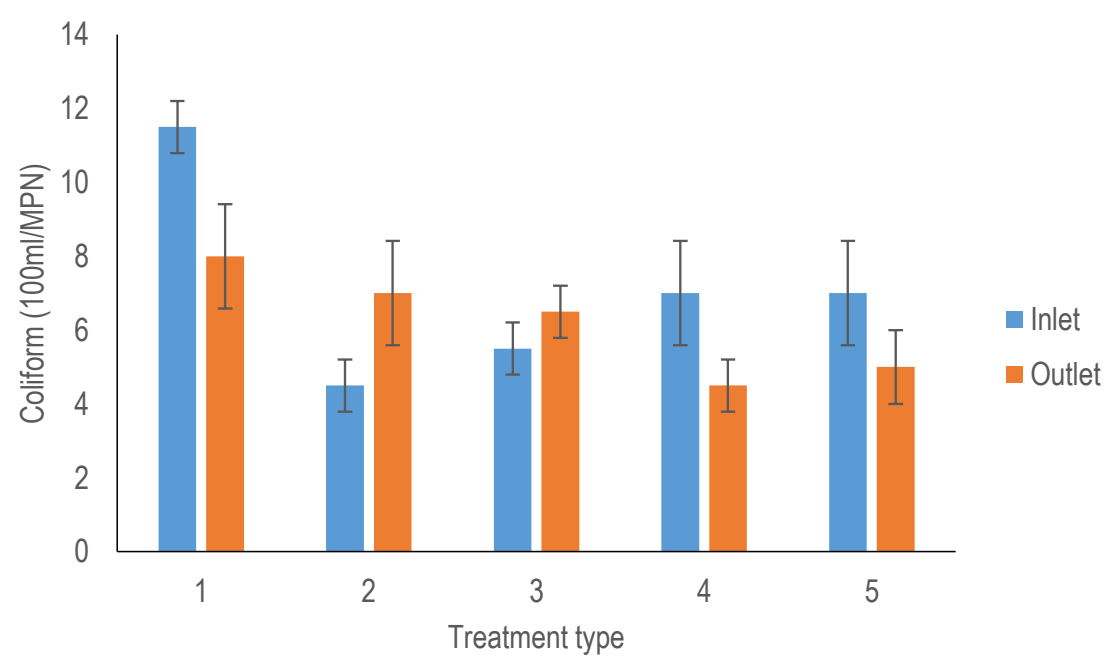

Fig. 4. Coliform bacteria in raw and treated RRWH

In this study, zeolite used in RRWH treatment can reduce coliform bacteria concentration. This ability also reported by Isholawati and his co-authors where zeolite can reduce the concentration of E-coli bacteria in groundwater (26). Furthermore, the used of zeolite as filter media in the pipe with diameter 6 ", 8", and 10 ", and it produced the highest absorption efficiency in the pipe of 10" with an efficiency of bacteria absorption of $96 \%$ (27).

This type of coliform bacteria was present in rainwater because the rainwater might be contaminated with faecal coliform material deposited on the rooftop of the building by animals, rodent, or birds (28) or even due to environmental conditions surrounding the test site (29). In an unclean environment condition coliform bacteria able to multiply rapidly and contaminate the water (30).

\section{Conclusion}

This study has presented a case study in the campus of the State University of Malang to evaluate the RRWH quality and to discuss the potential of rainwater as an alternative to 
clean water supply on the campus. The research results showed that rainwater in campus met the water quality standard as a clean water source. Although three of the water quality parameters do not meet the standard, further treatment using filter media of zeolite and activated carbon has proven to reduce the concentration of TDS, $\mathrm{KMnO}_{4}$, and coliform bacteria. T4 could eliminate about $37 \%$ and $36 \%$ for TDS and coliform bacteria, respectively. While $\mathrm{T} 5$ was reported effective to reduce organic substances that presented as $\mathrm{KMnO}_{4}$ for $35 \%$. Further study is needed to improve the treatment of rainwater as a clean water source.

\section{References}

1. B. A. Suprapto, 0-6 (2015)

2. M. M. Haque, A. Rahman \& B. Samali, Journal of Cleaner Production, 137 60-69 (2016)

3. D. N. Khaerudin, W. D. Proborini \& G. D. Pandulu, Eco Rekayasa, 9 150-157 (2009)

4. B. K. Biswas \& B. H. Mandal, ISRN Otolaryngology 1-6 (2014)

5. J. O. Rahmawati \& Nurhayati, 14 (2010)

6. T. Untari \& J. Kusnadi, Jurnal Pangan Dan Agroindustri, 4 1492-1502 (2015)

7. Fatahilah \& I Raharjo, Jurnal Zeolit Indonesia, 6 43-46 (2007)

8. S. Agmalini, N. N. Lingga, \& S. Nasir, Jurnal Teknik Kimia, 19 59-68 (2013)

9. S. Munfiah \& O. Setiani, Kesehatan Lingkungan Indonesia, 12(2), 154-159. (2013).

10. Metcalf and Eddy, Wastewater Engineering, Treatment and Reuse. New York: Mc Graw Hill (2004)

11. H. Mohammed, I. A. Hameed \& R. Seidu, Science of The Total Environment. 628-629 1178-1190 (2018)

12. WHO. Health Criteria and Other Supporting Information, 28 (1996)

13. Sulastri \& I. Nurhayati, Pengaruh Media Filtrasi Arang Aktif Terhadap Kekeruhan, Warna, dan TDS pada Air Telaga di Desa Balongpanggang, $1243-47$ (2014)

14. Nurmalita, Maulidia \& M. Syukri, Analisa Kekeruhan Dan Kandungan Sedimen Dan Kaitannya Dengan Kondisi Das Sungai Krueng Aceh (2013)

15. A. Kurniawan, B. Rahadi \& L. D. Susanawati, Sumberdaya Alam Dan Lingkungan, 38-46 (2014)

16. W. Nugroho \& S. Purwoto, Jurnal Teknik, 11 47-59 (2013)

17. S. S. Soesanto, Media Penelitian Dan Pengembangan Kesehatan, VI (1996)

18. S. Notodarmojo \& A. Deniva, PROC. ITB Sains \& Tek, 36 63-82 (2004)

19. S. Wang \& Y. Peng, Chemical Engineering Journal, 156 11-24 (2010)

20. S. M. Indriyati, Efektifitas zeolit Dalam Menurunkan Kadar Zat Organik pada Limbah Cair Industri Tahu di Kelurahan Krobokan Kecamatan Semarang Barat Kota Semarang (2001)

21. M. Aryanti, Penjernihan Air Sungai Lahan Gambut Menggunakan Karbon Aktif Gambut. Universitas Indonesia (2010)

22. Y. Sukawaty, M. Kamil \& E. Kusumawati, Jurnal Ilmiah Manuntung, 2 248-253 (2016)

23. Purwono \& Karbito, Jurnal Kesehatan Lingkungan Poltekkes Kemenkes Tanjungkarang, 4 305-314 (2013)

24. S. N. Atikah, Narto \& L. Hendrarini, Jurnal Kesehatan Lingkungan, 8 95-100 (2016)

25. Masthura \& E. Jumiati, Ilmu Fisika Dan Teknologi, 1 1-6 (2017)

26. D. Isholawati, E. F. Karamah, Z. A. Zufri \& A. N. Hidayat, Disinfeksi Bakteri Escherichia Coli Menggunakan Proses Kavitasi, 10-15 (2010)

27. D. Fakhrana, J. Mts \& I. Apriani, 82 1-10 (2014)

28. M. Waso, S. Khan \& W. Khan, Environmental Research, $161446-455$ (2018) 
29. R. Asyfiradayati, Total Coliform Air hujan pada Tempat Penampungan Air Hujan (PAH) Skala Rumah Tangga Penduduk Kabupaten Lamongan 37-40 (2009)

30. T. Hartuna, Udiantoro \& L. Agustina, Desain Water Treatment Menggunakan Karbon Aktif dari cangkang Kelapa Sawit pada Proses Pengolahan Air Bersih di Sungai Martapura, 39 136-144 (2014) 